\title{
Psychoanalysis and Countermeasures of Oral English Learning Disabilities of Vocational College Students
}

\section{Yapeng Li}

Party Committee Propaganda Department, Hubei Three Gorges Polytechnic, Yichang, Hubei, 443000, China

Keywords: vocational college students; oral English; learning disabilities; psychology

\begin{abstract}
Oral English teaching has always been a difficult point in higher vocational colleges. How to effectively overcome the students' psychological barriers on oral English learning and improve the effect of learning is the focus of English teachers in higher vocational colleges when exploring teaching reform. This paper makes an appropriate study on the English oral learning disabilities of vocational college students from the perspective of psychology and puts forward suggestions for promoting teaching reform based on the demand of higher vocational colleges on talent training, in order to gradually promote the teaching of oral English in vocational college and improve the comprehensive development effect of talent training in higher vocational colleges.
\end{abstract}

\section{Introduction}

Most of the vocational college students do not have strong English learning ability. Their English foundation is weak and they have resistance on oral English. Some of them even have psychological barriers to oral English learning, which greatly dispels the students' enthusiasm for English learning. To a certain extent, students' comprehensive learning ability is seriously affected, and it also has a negative impact on the cultivation of the ability of English communication. Therefore, in the process of reforming and innovating talents training in vocational colleges, it is necessary to carry out effective psychological guidance activities for oral English learning. Through this way they can have a correct learning attitude and actively participate in learning and research activities and then gradually enhance their oral English communication skills.

\section{The Status Quo of Oral English Teaching in Vocational Colleges}

Under the circumstances that China is comprehensively promoting international economic exchanges, the cultivation of English skills for vocational talents has been attached widespread attention. One of the urgent problems for the higher vocational colleges is to improve students' comprehensive English quality. However, due to some factors, in the process of implementing oral English teaching in higher vocational colleges, the teaching effect is not as good as expected, and even seriously hinder the students' future career development. On the one hand, some English teachers still adopt a teacher-centered teaching model, which neglects the subjectivity of oral English learning, and they do not attach importance to the communication with students in teaching practice, which leads to students' low interest in oral English learning, insufficient participation in the classroom, and non-ideal oral learning and training results. On the other hand, English teachers in vocational colleges are conservative in terms of selecting oral teaching methods. The teaching methods they use are tedious and cannot stimulate students' interest in oral learning. In particular, without practical situational communications, the effect of students' oral training is greatly limited, and the goal of gradual improvement cannot be achieved. In addition, students' poor oral English and lack of confidence in learning are also important factors limiting the optimization of oral English teaching. Therefore, we should pay attention to the basic situation of oral English teaching in vocational colleges, actively explore measures for reform and innovation of teaching activities to guide students to gradually overcome psychological barriers in English learning, so as to enhance their confidence in oral training, and gradually realize the good training of oral English 
communication skills to the students

\section{Obstacles in Oral English Learning of Vocational College Students from the Perspective of Psychology}

This paper studies and analyzes the psychological barriers in the oral English learning process of vocational college students from the perspective of psychology, and it is found that there are many aspects of psychological barrier factors. Only by analyzing and researching students' English learning from multiple angles can we put forward reasonable suggestions, so as to effectively promote the training of students' oral English learning ability. According to the specific analysis, the obstacles in the English oral learning of vocational college students involve the following aspects from the perspective of psychology:

First, the students have weak English foundation, and they are self-contemptuous on oral English. The vocational college students have weak English foundation and poor learning ability. Without professional guidance and effective communication, students have a wrong orientation in their English learning, especially they are not confident in English learning and training and unwilling to participate in practical training activities, resulting in the development of English speaking ability is greatly limited.

Second, the teaching methods used by teachers are relatively old-fashioned and cannot stimulate students' interest in learning. As a result, students lack motivation in the process of participating in oral English learning, and they have no enthusiasm of continuous learning and exploration, so the effective cultivation of oral English can be realized.

Third, students are afraid to learn oral English. Due to the inability to experience the learning effect of oral training for a long time, students may be tired of oral English learning, and the comprehensive learning effect may also be affected, which is not conducive to the improvement of students' comprehensive English learning ability.

Therefore, in the reform and innovation of oral English teaching in higher vocational colleges, teachers should grasp the factors of students' learning psychological barriers, formulate diversified teaching strategies, and implement more effective teaching to ensure that students can gradually overcome psychological barriers; Stimulate students' interest in oral English learning and achieve the development of teaching activities.

\section{Teaching Strategy of Gradually Improving Vocational College Students' Oral Ability}

In the process of reform and innovation of English teaching in higher vocational colleges, in order to enhance students' confidence in oral English learning and comprehensively improve the practical effect of teaching organization activities, teachers should formulate corresponding teaching programs based on the psychological characteristics of students to enhance the fun of teaching activities; stimulate students' interest in learning and exploration, comprehensively improve the learning effect of oral English, and create favorable conditions for the cultivation of oral communicative competence.

\subsection{Optimize basic knowledge teaching and motivate students' interest in oral English learning}

The English foundation of students in vocational colleges is poor, and it is difficult for them to study oral English knowledge. Therefore, in the teaching organization activities, the primary task of teachers is to optimize the teaching of basic knowledge teaching. On the basis of improving students' English learning ability, introduce interesting oral communication content, then reform and innovate teaching activities, enhance the fun and attractiveness of teaching activities, to ensure students actively participate in oral training activities, and achieve the cultivation of students' oral communication skills.

For example, teachers can make appropriate adjustments to pre-school preparation teaching based on the strengthening of basic knowledge teaching. Let students collect interesting English knowledge 
in daily lives, randomly select a student to read out the collected English sentences, and other students translate the interesting English knowledge, and try to imitate, so that students can feel the fun in oral English training and stimulate their interest in learning. For example, a student reads two English sentences: "The early bird might get the worm, but the second mouse gets the cheese./War does not determine who is right - only who is left." Teachers organize students to translate on the basis of imitating reading, and to combine the knowledge they have learned to translate and explore the interesting elements contained therein. The first sentence can be translated as "早起的鸟儿有虫吃, 但是晚到的老鼠才有奶酷。" Some students also translate their words into their own understanding, translated as "早起的鸟儿有虫吃, 早起的虫儿被鸟吃". This kind of translation activity not only strengthens the students' basic knowledge of English, but also gradually motivate their interest in English learning, and then they are willing to actively conduct oral English training.

\subsection{Innovate teaching method and build funny class environment}

In the reform and innovation of oral English teaching activities in vocational colleges, it is necessary not only to stimulate students' interest in learning, but also to guide students to actively learn and explore oral knowledge. It is also necessary to recognize the importance of guiding students to get rid of inferiority and ensure that students can get good learning effect. Therefore, in teaching activities, teachers need to use advanced educational concepts to innovate teaching methods, create situational teaching methods, emotionally stimulating teaching methods, and task-driven teaching methods, so that students can gradually try to use English to communicate with others and correct students' bad mood in English oral training so as to improve the students' comprehensive English learning effect .

In specific teaching activities, teachers may introduce situational teaching methods to stimulate students' emotions in specific oral training situations, so that students' oral English ability can be trained. For example, in the oral training activities, teachers may let students to watch clips of classic movies, allowing them to accumulate corresponding English materials on the basis of watching movies and feeling the fun of learning [4]. For example, in the movie clips collected by the teachers, including classic lines inlcuding Stupid is as stupid does.(young Forrest)/Frankly my dear, I don't give a damn.((Rhett Butler)/What we have here is a failure to communicate.(Cool Hand Luke)/You're gonna need a bigger boat.(Police Chief Martin Brody)/I feel the need - the need for speed. (Maverick) /I'm the king of the world. (Jack Dawson)/You can't handle the truth.(Colonel Jessup), which is analyzed by the students with the guidance of teachers. Instruct students to randomly select a line, then set up a scene with their peers and apply the line to oral communication. In this way, the students' interest to oral English has been appropriately stimulated, and the classic lines are used as a blueprint to design oral communication dialogue, which reduces the difficulty of oral training. This is conducive to the development of students' confidence in oral training.

\subsection{Evaluate at multiple perspectives and encourage students in oral English trainings}

In the process of practical exploration of English teaching activities in vocational colleges, English teaching evaluation has an important influence on students' oral learning and training confidence. Therefore, teachers should introduce diversified evaluations for students' oral training performance, and combine teacher evaluation, group evaluation and student self-evaluation. Give play to the role of teacher-led evaluation, discover the students' merits and praise and encourage them in a timely manner, and make corresponding positive guidance for the evaluation of other students, so as to realize the students' interest in oral English learning and avoid students' resistance on learning. For example, for students' classroom performance, teachers can use incentive language to implement evaluation incentives for students. You said it is great! /Your progress is too obvious! /Your pronunciation is more standard!/ You can now express your opinion smoothly! In the future you will be the best English communicator. In this way, effective incentive evaluation can strengthen students' confidence in English training, and can encourage students in higher vocational colleges to actively participate in oral English learning and training activities, truly get rid of the constraints of psychological barriers, and achieve remarkable results in oral English learning and lay the foundation 
for the overall development of students.

\section{Summary}

All in all, in the process of oral English teaching for students in vocational colleges, we must objectively understand the psychological barriers of students and study them from the perspective of psychology. Conduct emotional communication and spiritual communication with students to guide them to overcome their barriers in learning and exploration and actively explore oral English learning, to ensure that they have a good experience in the process of learning oral English, and gradually improve their English speaking ability.

\section{References}

[1] Wu Min. On the Barriers of Oral English Learning in Vocational Colleges and Countermeasures, Campus English, 2017(9):79-80.

[2] Wang Jing. Oral English Learning Disabilities of Junior High School Students and Countermeasures, Campus English, 2017(6):192-192.

[3] Zhang Yujing. Exploration and Solution of the Causes of Oral English Communication Disorders of Vocational College Students, Curriculum Education Research: Study of Learning Methodology, 2016(16):73-74.

[4] Zhang Xuan. Analysis of Middle School Students' Oral English Learning Disabilities and Teaching Strategies, Chinese Out-of-School Education, 2017(33):84-84.

[5] Zhu Xiaoping. Obstacles and Countermeasures of Oral English Teaching in Primary Schools, Campus English, 2017(28):158-158. 